E. Liveri, P. Bareka \& G. Kamari

\title{
Karyosystematic study of some taxa from Campanula section Quinqueloculares (Campanulaceae). I.
}

\begin{abstract}
Liveri, E., Bareka, P. \& Kamari, G. 2020: Karyosystematic study of some taxa from Campanula section Quiqueloculares (Campanulaceae). I. [In Kamari, G., Blanché, C. \& Siljak-Yakovlev, S. (eds), Mediterranean plant karyological data-30]. - F1. Medit. 30:440-455. http://dx.doi.org/10.7320/FlMedit30.440

Chromosome numbers and karyotypes are given for 12 taxa of Campanula section Quinqueloculares. All the examined taxa are distributed in Greece including the phytogeographical regions of Crete and Karpathos, Cyclades and East Aegean Islands. The chromosome number $2 n=2 \mathrm{x}=34$ is found in all examined taxa with the exception of C. laciniata $(2 n=4 \mathrm{x}$ $=68$ ), which is a new chromosome number for the taxon from Crete. Their karyotypes are symmetrical comprising of mostly metacentric and submetacentric chromosomes, small in size, but they differ in the presence and the size of satellites. The chromosome count $(2 n=34)$ and karyotype morphology of $C$. topaliana subsp. delphica is given for first time. New populations of C. cymaea, C. kamariana, C. pelviformis, and C. topaliana subsp. cordifolia were karyologically investigated confirming the previous references. The karyotype morphology of $C$. anchusiflora, C. andrewsii subsp. hirsutula, C. kamariana, C. lavrensis, C. merxmuelleri, C. nisyria, and $C$. rupestris is given for first time. Additionally, microphotographs are firstly provided hereby for all investigated taxa.
\end{abstract}

Keywords: Chromosome number, distribution, endemism, Greece, karyomorphology.

\section{Introduction}

Campanula L. section Quinqueloculares (Boiss.) Phitos encompasses ca. 39 species mostly distributed in Greece and/or W Turkey (Liveri \& al. 2019). Only two of the species (C. crispa Lam., C. lyrata Lam.) extend their distribution to Transcaucasia, Armenia, Iran and Jordan, whereas one species $(C$. medium L.) is restricted to Italy and France (Castroviejo \& al. 2010). Greece and W Turkey harbor 24 and 12 species, respectively, in addition to 2 species ( $C$. hagielia Boiss. and $C$. lyrata) which occur both in East Aegean Islands and the adjacent Turkish coastline.

The species of Campanula sect. Quinqueloculares are characterized by an extreme morphological polymorphism, which renders their identification hard, or even dubious in some cases (Phitos 1965, 1969, 2016; Eddie \& Ingrouille 1999). In general, they are biennial (monocarpic) or, more rarely, perennial plants, mostly chasmophytic, featured by a 5 -locular ovary, style with 5 stigmas, capsule opening with 5 pores, and calyx 
appendages more or less covering the ovary (Phitos 1965, 1969; Liveri \& al. 2019, 2020). However, in some species, the number of the ovary locules varies from 3 to 5 (Liveri \& al. 2019, 2020). A small group of six species with a predominantly trilocular ovary has been recognized by Phitos (1963a) and referred to as "Campanula rupestris group" or "trilocular Campanula species" (Phitos 1964a) or "Triloculares" (Phitos 2016). Recently, the first phylogenetic study of C. sect. Quinqueloculares based on molecular data was performed revealing the polyphyletic origin of the traditionally circumscribed section (Liveri \& al. 2020).

Karyological studies of 28 species belonging to Campanula sect. Quinqueloculares resulted in a consistent chromosome count $(2 n=2 \mathrm{x}=34)$ for all of them (Marchal 1920; Phitos 1963a, b, 1964a, b, 1965, 1969; Contandriopoulos 1964, 1970; Gadella 1964; Zhukova 1967; Tornadore \& al. 1974; Papatsou \& Phitos 1975; Phitos \& Kamari 1984; Montmollin 1986; Runemark \& Phitos 1996; Strid 2015; Kyriakopoulos \& al. 2017). The chromosome number $2 n=2 \mathrm{x}=32$ given in $C$. medium (Chen $\&$ al. 2003), is questionable.

Polyploidy is not common in $C$. sect. Quinqueloculares. So far, the only known polyploidy number is $2 n=6 \mathrm{x}=102$ in C. laciniata L. (Sugiura 1942).

Although the chromosome number for the majority of the species has been given in the past, the karyotype morphology of most species is still unknown.

The current karyological study provides chromosome number, ploidy level, type of symmetry and average maximum and minimum length of chromosomes. For each taxon, karyotype microphotograph is also provided and karyotype morphology is discussed.

1982. Campanula anchusiflora Sm. $-2 n=2 \mathrm{x}=34$ (Figs $1 \mathrm{a}, 2 \mathrm{a} \& 2 \mathrm{~b}$ ).

Gr: Isl. Hydra: W side of the port, on the coastal road from the port towards Kamini village, alt. 6-10 m., $37^{\circ} 21^{\prime} 5^{\prime}$ N, 23 27' 51" E, 27 Apr 2016, leg. E. Liveri \& V. Ketsilis-Rinis 188 (Herb. Phitos \& Kamari in UPA).

Campanula anchusiflora (Fig. 1a) is a typical quinquelocular species restricted in Hydra island (Argosaronikos Gulf). However, morphologically deviating forms can be found on the adjacent mainland in Peloponnisos (Phitos 1965, 1969).

One population of Campanula anchusiflora in material from Hydra has been studied karyologically resulted to the chromosome number $2 n=34$ (Phitos 1963a, 1969).

The chromosome number $2 n=34$ for Campanula anchusiflora in material from Hydra is confirmed in our study. The karyotype is diploid and symmetrical, consisting of mostly metacentric $(\mathrm{m})$ and submetacentric $(\mathrm{sm})$ chromosomes which vary in size between 1.00-1.55 $\mu \mathrm{m}$ (Fig. 2a; Table 1). In several karyotypes of the examined material, two submetacentric ( $\mathrm{sm}$ ) chromosomes are observed, bearing large satellites, similar in size to the short (s) arm (Fig. 2b). Due to the heterochromatin structure and the long distance from the short arm caused by the squashing technique, these satellites can be considered as B-chromosomes. The given chromosome number is confirmed by previous studies (Phitos 1963a, 1969); microphotographs of the karyotype are presented here for the first time (Figs $2 a, b)$. 

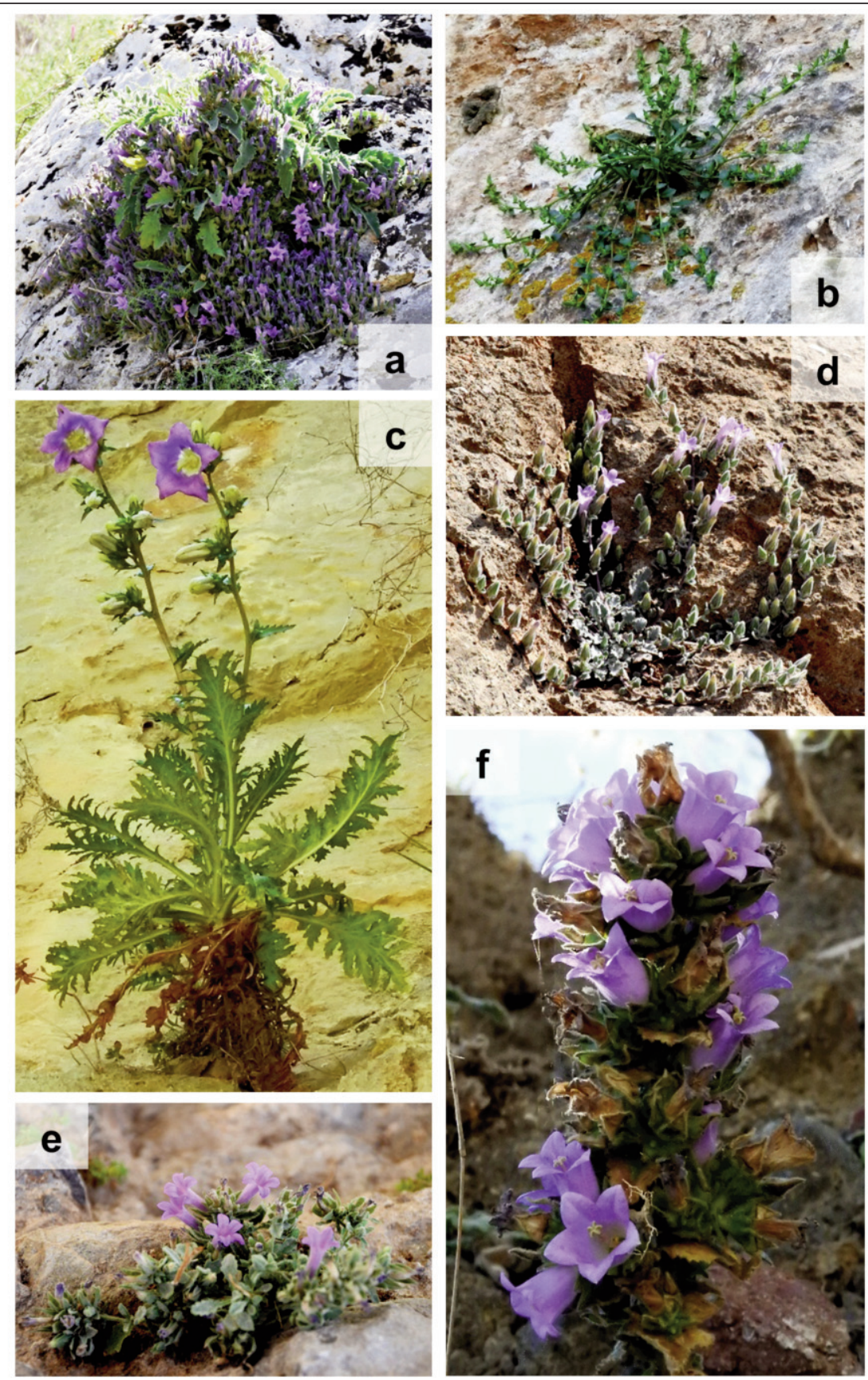

Fig. 1. Some taxa of Campanula section Quinqueloculares: a, C. anchusiflora (Hydra); b, C. merxmuelleri (Skyros); c, C. laciniata (Crete); d, C. topaliana subsp. delphica (Delphi); e, C. andrewsii subsp. hirsutula (Monemvasia); f, C. nisyria (Nisyros). - Photos by E. Liveri. 
1983. Campanula andrewsii subsp. hirsutula Phitos $-2 n=2 \mathrm{x}=34$ (Figs 1e \& 2c).

Gr: $\quad$ Prov. Lakonia: Castle of Monemvasia, alt. 0-5 m., 36 $46^{\prime}$ N, $23^{\circ} 03^{\prime}$ E, 21 May 2016, leg. E. Liveri \& V. Ketsilis-Rinis 225 (Herb. Phitos \& Kamari in UPA).

Campanula andrewsii is distributed in eastern Peloponnisos. It comprises of two subspecies: 1) the typical subsp. andrewsii, mostly growing in northeastern Peloponnisos (Argolis peninsula, Korinthos); and 2) subsp. hirsutula (Fig. 1e), which was originally described from the castle of Monemvasia (locus classicus) and it is also found in southeastern Peloponnisos (Phitos 1965, 1969; Fedorov \& Kovanda 1976) and in a single locality of northeastern Peloponnisos, in Methana peninsula (Kougioumoutzis \& al. 2012a). C. andrewsii subsp. hirsutula differs morphologically from the typical subspecies mainly in its indumentum (hirsute calyx), corolla (shorter tube) and calyx appendages (very short and acuminate) (Phitos 1965, 1969; Fedorov \& Kovanda 1976).

The chromosome count $2 n=34$ has been recorded in material from the locus classicus (Phitos 1965, 1969). Additionally, Contandriopoulos (1964) reports the same chromosome number and provides a karyotype drawing for C. andrewsii s.1. in material from Mt. Parnassos, but most probably refers to a different taxon.

The examined material of $C$. andrewsii subsp. hirsutula shows a diploid, symmetrical karyotype comprised of $2 n=2 \mathrm{x}=34$ chromosomes, mainly metacentric (m) and submetacentric (sm), varying in size between 1.02 and $1.45 \mu \mathrm{m}$; one submetacentric (sm) chromosome pair bears large satellites (Fig. 2c; Table 1). Previous karyological references confirm the same chromosome number (Phitos 1965, 1969); although, the karyotype morphology and microphotograph are presented here for first time.

1984. Campanula cymaea Phitos $-2 n=2 \mathrm{x}=34$ (Fig. $2 \mathrm{~d}$ ).

Gr: Isl. Evia: village Vrysi, $15 \mathrm{~km} \mathrm{SW}$ of the town Kymi, alt. $115 \mathrm{~m}$., 38 33'06.56" N, 2402' 38.57' E, 6 May 2017, leg. E. Liveri, V. Ketsilis-Rinis \& N. Cellinese 294 (Herb. Phitos \& Kamari in UPA).

Campanula cymaea is a representative of "Triloculares", endemic to eastern part of central Evia, especially around the town of Kymi (Phitos 1969; Phitos \& Kamari 1995). It is included in the first Red Data Book of Rare and Threatened Plants of Greece as Rare (R), according to IUCN (1994) criteria (Phitos \& Kamari 1995) and in the Greek Presidential Decree 67/1981.

The chromosome count $2 n=2 \mathrm{x}=34$ has been reported in material from two localities (Kymi and Potamia) accompanied with a karyotype drawing indicating one pair of large SAT-chromosomes (Phitos 1964a, 1969). Phitos (1964a) notices structural heterozygosity in the satellited pair in most individuals of the second population.

The examined material of Campanula cymaea is also diploid $(2 n=2 \mathrm{x}=34)$ and has a symmetrical karyotype which includes mostly metacentric ( $\mathrm{m}$ ) and submetacentric $(\mathrm{sm})$ chromosomes; one submetacentric $(\mathrm{sm})$ chromosome pair bears satellites (Fig. 2d). The average maximum and minimum chromosome length equals to $0.86 \mu \mathrm{m}$ 
and $1.25 \mu \mathrm{m}$, respectively (Table 1). The chromosome count and karyotype morphology of the newly examined subpopulation of C. cymaea is in accordance with previous studies (Phitos 1964a, 1969), but a microphotograph of the karyotype is provided for the first time (Fig. 2d).

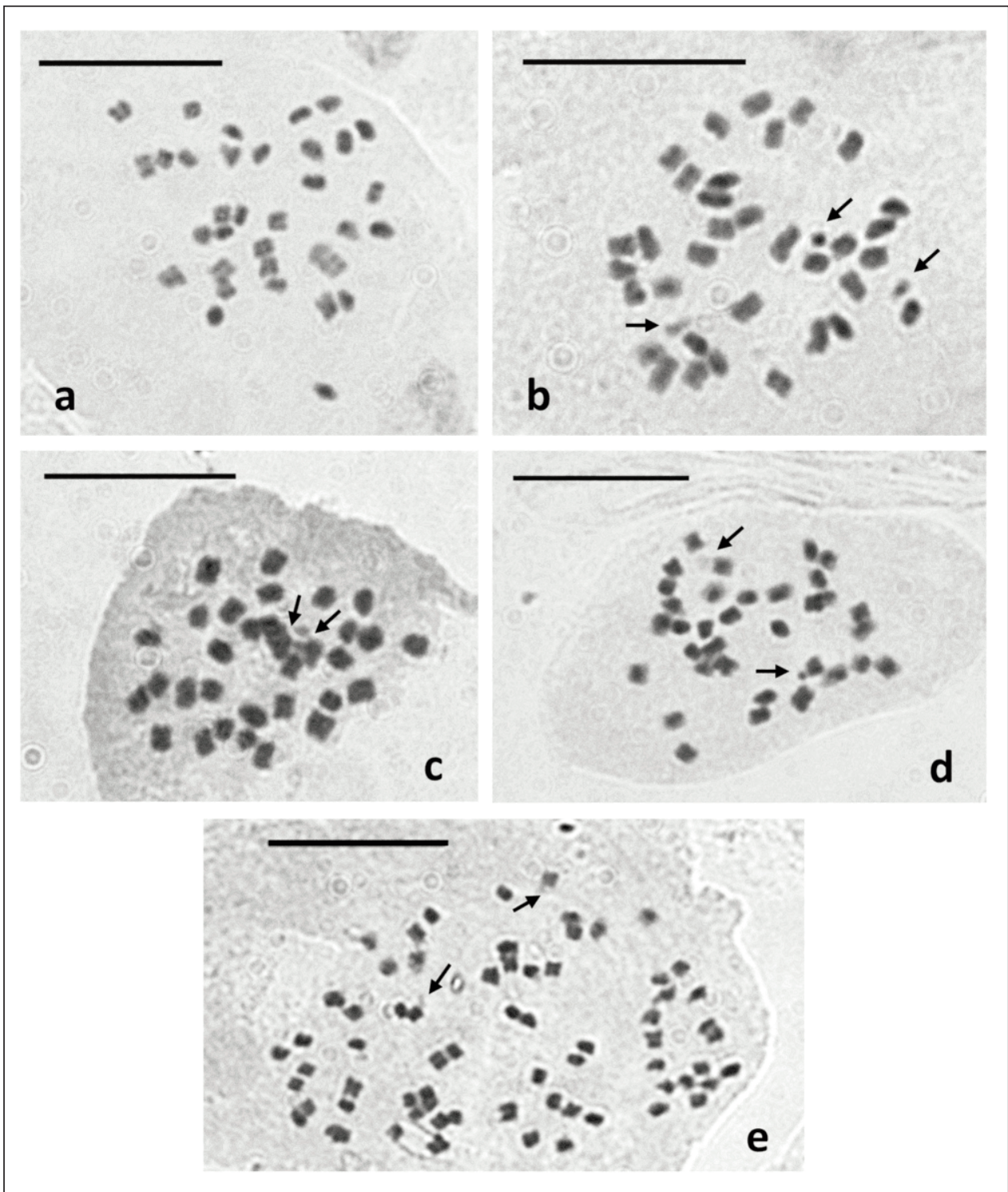

Fig. 2. Microphotographs of mitotic metaphase plates of Campanula section Quinqueloculares: a, and $\mathbf{b}, C$. anchusiflora, $2 n=34 ; \mathbf{c}, C$. andrewsii subsp. hirsutula, $2 n=34 ; \mathbf{d}, C$. cymaea, $2 n=34$; $\mathbf{e}$, C. laciniata, $2 n=68$. - Arrows indicate satellites. Scale bars $=10 \mu \mathrm{m}$. 
1985. Campanula kamariana Kyriak., Liveri \& Phitos $-2 n=2 \mathrm{x}=34$ (Fig. 3a).

Gr: Prov. Lakonia: south of village Itilo, castle of Kelefa, alt. 230 m., 36 $42^{\prime} 4.385^{\prime \prime} \mathrm{N}$, $22^{\circ} 23^{\prime} 47.327^{\prime \prime}$ E, 17 Jun 2018, leg. E. Liveri \& V. Ketsilis-Rinis 237 (Herb. Phitos \& Kamari in UPA).

Campanula kamariana is a recently described species of C. sect. Quinqueloculares, which is easily distinguished from the other species of the section mostly by its strongly lacerate, sparsely pubescent to glabrescent rosette leaves with long, sparsely lobed petioles (Kyriakopoulos \& al. 2017). Up to now, it is found in the description locality, i.e. Limeni, a small village closes to the town Areopolis (Messinian Bay - southern Peloponnisos) and a second locality firstly mentioned in the current study, i.e. the castle of Kelefa.

Concerning karyology of Campanula kamariana from the locus classicus, Kyriakopoulos \& al. (2017) mention the chromosome number $2 n=34$ and a symmetrical karyotype including mostly metacentric (m) chromosomes.

The examined material of Campanula kamariana shows also a diploid and symmetrical karyotype $(2 n=2 \mathrm{x}=34)$ comprised of mostly metacentric $(\mathrm{m})$ and submetacentric (sm) chromosomes, varying in size from 0.73 to $2.05 \mu \mathrm{m}$ (Fig. 3a, Table 1). One submetacentric $(\mathrm{sm})$ chromosome pair is predominantly observed bearing large satellites. The chromosome number of $C$. kamariana is confirmed from a new subpopulation with the addition of a microphotograph. The presence of satellited chromosomes is firstly mentioned hereby (Fig. 3a).

1986. Campanula laciniata Lam. $-2 n=4 \mathrm{x}=68$ (Figs $1 \mathrm{c} \& 2 \mathrm{e})$.

Cr: Prov. Chania: Aradaina gorge, alt. 70 m., $35^{\circ} 12^{\prime} 22.410^{\prime}$ N, $24^{\circ} 3^{\prime} 12.084^{\prime \prime}$ E, 10 May 2017, leg. E. Liveri, V. Ketsilis-Rinis \& N. Cellinese 289 (Herb. Phitos \& Kamari in UPA).

The large, broadly campanulate flowers and the laciniate, rather thick rosette leaves render C. laciniata (Fig. 1c) among the most showy and distinct members of Campanula sect. Quinqueloculares (Phitos 1965, 1969, 1995a; Cellinese \& al. 2009; Strid 2016a, 2016b; Liveri \& al. 2020). Campanula laciniata is distributed in the extended Cretan area (Crete and Karpathos), the southern Cyclades (Amorgos, Anafi, Folegandros, Kardiotisa, Sifnos, Sikinos), and Dodekanissos islands (Astypalea) (Phitos 1964b, 1965, 1969; Greuter 1973; Fedorov \& Kovanda 1976; Phitos \& Kamari 1984; Fielding \& Turland 2005; Cellinese \& al. 2009; Kougioumoutzis \& al. 2012b; Strid 2016a, 2016b; Liveri \& al. 2020). The populations of $C$. laciniata are scattered, consisting of a few individuals. This species is included in the first Red Data Book of Rare and Threatened Plants of Greece as Rare (R), according to IUCN (1994) criteria (Phitos 1995a), as well as in the Greek Presidential Decree 67/1981.

Diploid and hexaploid populations have been reported for Campanula laciniata: $2 n=$ $2 \mathrm{x}=34$ chromosomes are reported in material from Folegandros (Phitos 1964b) and Karpathos (Phitos \& Kamari 1984); while Sugiura (1942) reports an hexaploid karyotype with $2 n=6 \mathrm{x}=102$ chromosomes, from Greek material of an unknown locality. 


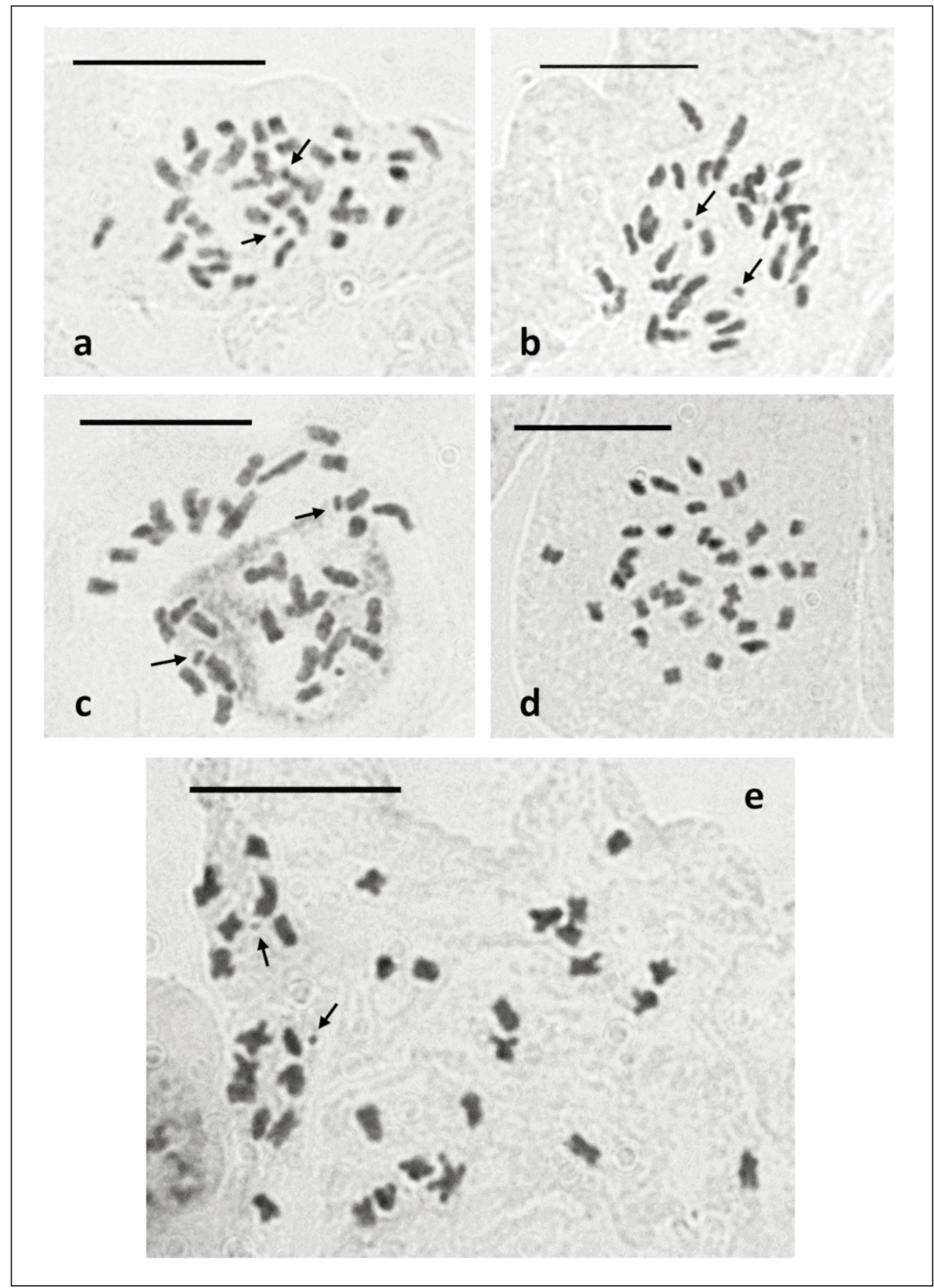

Fig. 3. Microphotographs of mitotic metaphase plates of Campanula section Quinqueloculares: a, $C$. kamariana, $2 n=34 ; \mathbf{b}$, C. lavrensis, $2 n=34 ; \mathbf{c}$, C. merxmuelleri, $2 n=34 ; \mathbf{d}$, C. pelviformis, $2 n=34$; e, C. nisyria, $2 n=34$. - Arrows indicate satellites. Scale bars $=10 \mu \mathrm{m}$. 
Our results reveal a new ploidy level for Campanula laciniata in material from Crete, which is studied karyologically for the first time here. The tetraploid chromosome count for the species is $2 n=4 \mathrm{x}=68$ chromosomes. The karyotype is symmetrical including mainly metacentric (m) and submetacentric ( $\mathrm{sm}$ ) chromosomes; four chromosomes have small spherical satellites, not all of them always visible (Fig. 2e). The chromosome size ranges from 0.78 to $1.29 \mu \mathrm{m}$ (Table 1 ). The chromosome morphology of the Cretan population is similar to that given for diploid population in material from Folegandros (Phitos 1964b). According to the karyotype drawing for the latter material, four SAT-chromosomes are observed (Phitos 1964b), in accordance with our results. The karyotype of C. laciniata is depicted for the first time with a microphotograph here (Fig. 2e).

1987. Campanula lavrensis (Tocl \& Rohlena) Phitos $-2 n=2 \mathrm{x}=34$ (Fig. 3b).

Gr: Prov. Chalkidiki: Athos peninsula, Moni Megistis Lavras, alt. 154 m., 40 $10^{\prime} 14.23$ ” N, 242 23' 2.88' E, 5 Jun 2018, leg. A. Karydas s.n. (UPA 24662).

The northest distribution limit of Campanula sect. Quinqueloculares is Athos peninsula, or commonly known in Greece as the Agion Oros, where Campanula lavrensis occurs (Phitos 1969; Fedorov \& Kovanda 1976). This species grows on the cliffs and old walls of the numerous monasteries located in this area. Due to its morphological variability, two varieties have been recognized: 1) var. lavrensis; and 2) var. breueri Phitos (Phitos 1965). According to Strid (2016a, b), material from Samothraki island also belongs to C. lavrensis, which previously was referred to as C. rupestris (Ade \& Rechinger 1938; Stojanov \& Kitanov 1944).

The only chromosome count given for Campanula lavrensis is $2 n=34$ in material from the locus classicus, i.e. Moni Megistis Lavras, which is the largest and oldest monastery in Athos peninsula (Phitos 1965, 1969).

The material of Campanula lavrensis examined here has a diploid $(2 n=2 \mathrm{x}=34)$ and symmetrical karyotype with metacentric ( $\mathrm{m}$ ) and submetacentric ( $\mathrm{sm}$ ) chromosomes, ranging from 1.06 to $1.99 \mu \mathrm{m}$ (Fig. 3b; Table 1). One pair of submetacentric (sm) chromosomes bears large satellites. The chromosome count confirms previous studies (Phitos 1965, 1969), but the karyotype morphology and a microphotograph are provided for first time.

1988. Campanula merxmuelleri Phitos $-2 n=2 \mathrm{x}=34$ (Figs $1 \mathrm{~b} \& 3 \mathrm{c}$ ).

Gr: Isl. Skyros: Mt. Kochilas, Monastery Agios Artemios, alt. 430 m., 38 51' 04.76” N, 24 35'39.72” E, 7 May 2017, leg. E. Liveri, V. Ketsilis-Rinis \& N. Cellinese 291 (UPA 24649).

One of the most distinct members of Campanula sect. Quinqueloculares is Campanula merxmuelleri (Fig. 1b), characterized by its glabrous and fleshy leaves combined with the entire petiole and elliptic-spathulate lamina (Phitos 1963b, 1965, 1995b; Phitos \& Kamari 2009; Liveri \& al. 2020). C. merxmuelleri is distributed in 
Skyros and adjacent small islands, as well as in Psara island (eastern Aegean) (Phitos \& Kamari 2009; Baliousis 2016). It is noteworthy that the first specimen from Psara island was collected by P. Saliaris in 2007 (kept in Herb. Phitos \& Kamari). Due to its peculiar distribution, it is considered as a relict endemic of the Aegean region (Phitos 2016). It is included in the Red Data Books of Rare and Threatened Plants of Greece as Vulnerable (VU), according to IUCN (1994, 2003) criteria (Phitos 1995b; Phitos \& Kamari 2009) and in the Greek Presidential Decree 67/1981.

The only chromosome count given for C. merxmuelleri is $2 n=34$ in material from the locus classicus, ie. Monastery Agios Artemios in Mt. Kochilas (Phitos 1963b, 1969). In the karyotype drawing of the species two SAT-chromosomes are indicated (Phitos 1969).

According to our data, Campanula merxmuelleri has $2 n=2 \mathrm{x}=34$ chromosomes, metacentric (m) and submetacentric ( $\mathrm{sm}$ ) in morphology, ranging in size between 1.18

Table 1. Chromosome data of the examined taxa of Campanula section Quinqueloculares. MAX and MIN correspond to average maximum and minimum length of chromosomes, respectively. SAT corresponds to the maximum number of observed SAT-chromosomes. All measurements are given in $\mu \mathrm{m}$. Standard Deviation (SD) is given in parenthesis.

\begin{tabular}{|l|c|c|c|c|}
\hline \multicolumn{1}{|c|}{ Taxon } & $\begin{array}{c}\text { Chromosome } \\
\text { number }\end{array}$ & SAT & MIN & MAX \\
\hline C. anchusiflora & $2 n=2 \mathrm{x}=34$ & 2 & $\begin{array}{c}1.00 \\
(0.08)\end{array}$ & $\begin{array}{c}1.55 \\
(0.13)\end{array}$ \\
\hline $\begin{array}{l}\text { C. andrewsii } \\
\text { subsp. hirsutula }\end{array}$ & $2 n=2 \mathrm{x}=34$ & 2 & $\begin{array}{c}1.02 \\
(0.12)\end{array}$ & $\begin{array}{c}1.45 \\
(0.12)\end{array}$ \\
\hline C. cymaea & $2 n=2 \mathrm{x}=34$ & 2 & $\begin{array}{c}0.86 \\
(0.05)\end{array}$ & $\begin{array}{c}1.25 \\
(0.08)\end{array}$ \\
\hline C. kamariana & $2 n=2 \mathrm{x}=34$ & 2 & $\begin{array}{c}0.73 \\
(0.16)\end{array}$ & $\begin{array}{c}2.05 \\
(0.38)\end{array}$ \\
\hline C. laciniata & $2 n=4 \mathrm{x}=68$ & 4 & $\begin{array}{c}0.78 \\
(0.05)\end{array}$ & $\begin{array}{c}1.29 \\
(0.24)\end{array}$ \\
\hline C. lavrensis & $2 n=2 \mathrm{x}=34$ & 2 & $\begin{array}{c}1.06 \\
(0.34)\end{array}$ & $\begin{array}{c}1.99 \\
(0.50)\end{array}$ \\
\hline C. merxmuelleri & $2 n=2 \mathrm{x}=34$ & 2 & $\begin{array}{c}1.18 \\
(0.31)\end{array}$ & $\begin{array}{c}2.49 \\
(0.72)\end{array}$ \\
\hline C. nisyria & $2 n=2 \mathrm{x}=34$ & 2 & $\begin{array}{c}0.91 \\
(0.08)\end{array}$ & $\begin{array}{c}1.95 \\
(0.19)\end{array}$ \\
\hline C. pelviformis & $2 n=2 \mathrm{x}=34$ & 0 & $\begin{array}{c}0.88 \\
(0.11)\end{array}$ & $\begin{array}{c}1.61 \\
(0.30)\end{array}$ \\
\hline C. rupestris & $2 n=2 \mathrm{x}=34$ & 2 & $\begin{array}{c}1.02 \\
(0.20)\end{array}$ & $\begin{array}{c}1.95 \\
(0.16)\end{array}$ \\
\hline $\begin{array}{l}\text { C. topaliana } \\
\text { subsp. cordifolia }\end{array}$ & $2 n=2 \mathrm{x}=34$ & 2 & $\begin{array}{c}0.85 \\
(0.17)\end{array}$ & $\begin{array}{c}1.73 \\
(0.39)\end{array}$ \\
\hline $\begin{array}{l}\text { C. topaliana } \\
\text { subsp. delphica }\end{array}$ & $2 n=2 \mathrm{x}=34$ & 2 & $\begin{array}{c}0.83 \\
(0.10)\end{array}$ & $\begin{array}{c}1.17 \\
(0.33)\end{array}$ \\
\hline
\end{tabular}


and $2.49 \mu \mathrm{m}$ (Fig. 3c, Table 1). The karyotype is symmetrical and diploid whereas two large satellites are observed in most karyotypes. Our findings are in accordance with previous studies (Phitos 1963b, 1969). Additionally, a microphotograph is provided here for first time (Fig. 3c).

1989. Campanula nisyria Papatsou \& Phitos $-2 n=2 \mathrm{x}=34$ (Figs $1 \mathrm{f} \& 3 \mathrm{e}$ ).

AE: Isl. Nisyros: Evangelistria, alt. 170 m., 36 36' 22.331" N, $27^{\circ}$ 8' $^{\prime} 41.394 ”$ E, 8 May 2018, leg. E. Liveri, V. Ketsilis-Rinis \& N. Cellinese 303 (UPA 24650).

Campanula nisyria (Fig. 1f) is endemic to the volcanic island Nisyros (Papatsou \& Phitos 1975). Nisyros is the easternmost active volcano of the South Aegean Volcanic Arc (Sachpazi \& al. 2002; Higgins 2009; Kougioumoutzis \& Tiniakou 2014). Additionally, it is the only oceanic island in the Aegean; i.e. it has never been connected to a continental landmass (Tibaldi \& al. 2008). After the first description of C. nisyria, Burton (1991) referred that it is an extreme isolated form of $C$. lyrata, while Strid (2016a) considered it as a synonym of $C$. hagielia. However, recent molecular data (Liveri \& al. 2020) reveal that $C$. nisyria belongs to a well-supported clade together with five Turkish endemics, whereas $C$. lyrata and $C$. hagielia form a different clade; both clades though are included in a larger clade comprised of Campanula taxa distributed in southeastern Aegean and Anatolia.

The only chromosome record $(2 n=34)$ for Campanula nisyria originates from the locus classicus (Papatsou \& Phitos 1975).

The karyotype of Campanula nisyria examined here is diploid $(2 n=2 \mathrm{x}=34)$, symmetrical, consisting of mostly metacentric $(\mathrm{m})$ and submetacentric ( $\mathrm{sm}$ ) chromosomes; two of them bearing small spherical satellites which are rarely found in this size in the section (Fig. 3e). The chromosome length varies from $0.91 \mu \mathrm{m}$ to $1.95 \mu \mathrm{m}$ (Table 1). The chromosome count is in accordance with the previous study by Papatsou \& Phitos (1975). However, the karyotype morphology and a microphotograph are provided here for first time (Fig. 3e).

1990. Campanula pelviformis Lam. $-2 n=2 \mathrm{x}=34$ (Fig. $3 \mathrm{~d}$ ).

Cr: Prov. Heraklio: New national road Iraklio-Agios Nikolaos, $42^{\circ} \mathrm{km}$, close to Malia, alt. 100-120 m., $35^{\circ} 18^{\prime} 24.563 "$ N, 2522' 43.745” E, 11 May 2017, leg. E. Liveri, V. Ketsilis-Rinis \& N. Cellinese 295 (Herb. Phitos \& Kamari in UPA).

Campanula pelviformis is endemic to Crete, growing mainly in the eastern part of the island (Phitos 1965; Fedorov \& Kovanda 1976; Fielding \& Turland 2005; Strid 2016a, b). Except from inhabiting calcareous cliffs and rocky slopes like the most of Campanula sect. Quinqueloculares species, C. pelviformis is also found growing along steep, rocky, roadside banks (Fielding \& Turland 2005; Cellinese \& al. 2009).

Phitos (1964b) reports the chromosome number $2 n=34$ for $C$. pelviformis in material from Crete of unknown locality and provides a karyotype drawing indicating two satellites. 
The same chromosome count has been also mentioned for the species in material of unknown origin by Sugiura $(1938,1942)$.

The examined material of Campanula pelviformis has a diploid $(2 n=2 \mathrm{x}=34)$ and symmetrical karyotype consisting of mostly metacentric $(\mathrm{m})$ and submetacentric $(\mathrm{sm})$ chromosomes (Fig. 3d). The chromosome length varies from $0.88 \mu \mathrm{m}$ to $1.61 \mu \mathrm{m}$ (Table 1). Our findings confirm previous studies (Sugiura 1938, 1942; Phitos 1964b), however, no SATchromosomes are observed in the material examined here. The karyotype is firstly presented with a microphotograph hereby (Fig. 3d).

1991. Campanula rupestris $\mathrm{Sm} .-2 n=2 \mathrm{x}=34$ (Fig. $4 \mathrm{a}$ ).

Gr: Prov. Viotia: Springs Krya, alt. 300-400 m., $38^{\circ} 25.908^{\prime}$ N, $22^{\circ} 52.540^{\prime}$ E, 5 May 2016, leg. E. Liveri, A. A. Crowl \& N. Cellinese 209 (UPA 24653).

Campanula rupestris is characterized by a consistently trilocular ovary with three stigmas, which is also found in other five species of the section; in total six species comprising the "C. rupestris group" (Phitos 1963a, 1964a). The species was discovered by Sibthorp, based on material from "Livadia" (Sterea Hellas) and was consequently described by Smith (Sibthorp \& Smith 1819). The exact locus classicus of C. rupestris was enigmatic since no more details of the locality were known, until Phitos re-discovered it in 1962 (see Phitos 1964a, 1995c, 2016). Before 1964, various Campanula taxa were erroneously referred to C. rupestris in literature causing much confusion due to the lack of herbarium material and the morphological variability of "C. rupestris group". Most likely, the species is also extended to Mt. Elikon (Phitos 1964a, 1995c). Eddie \& Ingrouille (1999) studied four populations of $C$. rupestris; two of them should be re-examined because of possible confusion with $C$. topaliana Beauverd subsp. delphica Phitos, while for one population the mentioned locality is rather unclear (Phitos 2016).

C. rupestris is recognized according to IUCN (1994) criteria as Vulnerable (VU) in the first Red Data Book of Rare and Threatened Plants of Greece (Phitos 1995c) and it is also included in the Greek Presidential Decree 67/1981.

The karyological study of Campanula rupestris from its locus classicus revealed $2 n=$ 34 chromosomes, accompanied with a karyotype drawing indicating one pair of SAT-chromosomes (Phitos 1964a). There are also two more references reporting the same chromosome number for $C$. rupestris in material from Peloponnisos (Phitos 1963a; Contandriopoulos 1964); most probably these references are related to C. topaliana subsp. cordifolia Phitos. Gadella (1964) also gives the same chromosome count for cultivated material of $C$. rupestris originated from England and the former Soviet Union.

The examined material of Campanula rupestris was also collected from the locus classicus and shows the same chromosome number and morphology. C. rupestris has diploid $(2 n=2 \mathrm{x}=34)$ and symmetrical karyotype, consisting of mostly metacentric (m) and submetacentric ( $\mathrm{sm}$ ) chromosomes with one pair of SAT-chromosomes (Fig. 4a). The chromosome length ranges from $1.02 \mu \mathrm{m}$ to $1.95 \mu \mathrm{m}$ (Table 1). Microphotograph is firstly provided hereby (Fig. 4a). 


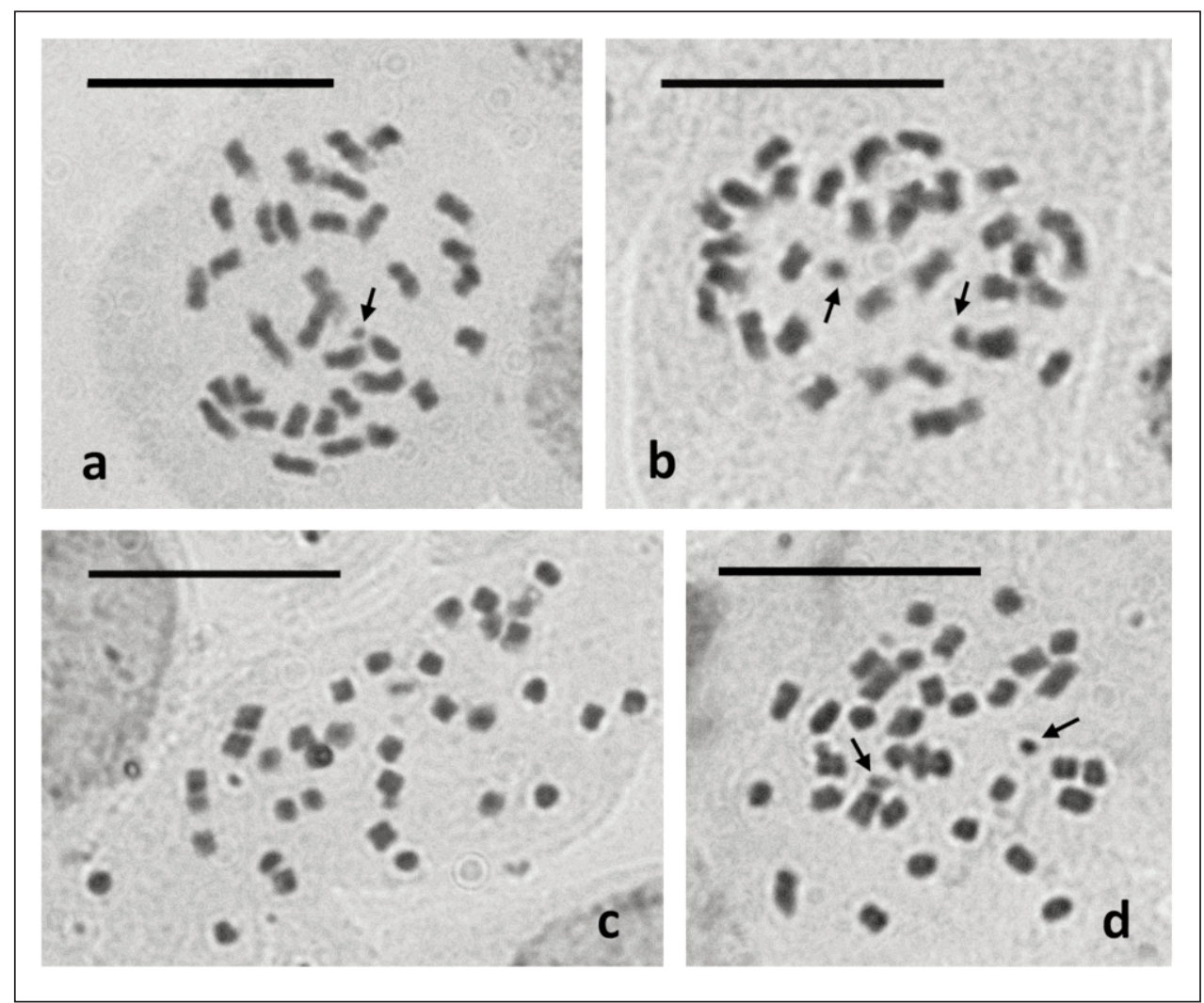

Fig. 4. Microphotographs of mitotic metaphase plates of Campanula section Quinqueloculares: a, $C$. rupestris, $2 n=34 ; \mathbf{b}, C$. topaliana subsp. cordifolia, $2 n=34$; $\mathbf{c}$, and d, C. topaliana subsp. delphica, $2 n=34$. - Arrows indicate satellites. Scale bars $=10 \mu \mathrm{m}$.

1992. Campanula topaliana subsp. cordifolia Phitos $-2 n=2 \mathrm{x}=34$ (Fig. 4b).

Gr: Prov. Ilia: Thermal springs of Kaiafas, alt. 0-5 m., 37 $30^{\prime} 52.49$ " N, $21^{\circ} 36^{\prime} 54.94$ " E, 8 Apr 2017, leg. E. Liveri \& V. Ketsilis-Rinis 266 (Herb. Phitos \& Kamari in UPA).

Campanula topaliana is a variable species which includes three subspecies sensu Phitos (1965): 1) subsp. topaliana, distributed in a very restricted region between Kalavryta and Monastery Agia Lavra (Prov. Achaia); 2) subsp. cordifolia, which occurs in the most part of Peloponnisos (Prov. Achaia, Argolida, Arkadia, Korinthia, Lakonia, Messinia); and 3) subsp. delphica, growing in Delphi (Prov. Fokida) and the nearby area. The three subspecies mainly differ in the shape of basal leaves and the size of corolla (Phitos 1965, 1969; Fedorov \& Kovanda 1976).

The chromosome count from a new population studied here is in accordance with previous reports (Phitos 1965, 1969) in material from locus classicus (Zachlorou near 
Kalavrita). The examined material shows a diploid $(2 n=2 \mathrm{x}=34)$, symmetrical karyotype, consisting of mostly metacentric (m) and submetacentric (sm) chromosomes; two large satellites are observed in most karyotypes (Fig. 4b). The chromosome length ranges from $0.85 \mu \mathrm{m}$ to $1.73 \mu \mathrm{m}$ (Table 1). Karyotype morphology and a microphotograph are given for first time here (Fig. 4b).

1993. Campanula topaliana subsp. delphica Phitos $-2 n=2 \mathrm{x}=34$ (Figs $1 \mathrm{~d}$, 4c \& 4d).

Gr: Prov. Fokida: close to Delphi, alt. 450 m., $38^{\circ} 29^{\prime} 15.21^{\prime}$ N, $22^{\circ} 28^{\prime} 11.37^{\prime \prime} \mathrm{E}, 9 \mathrm{Apr}$ 2017, leg. E. Liveri \& V. Ketsilis-Rinis 258 (Herb. Phitos \& Kamari in UPA).

Campanula topaliana subsp. delphica (Fig. 1d) differs from the other subspecies in its grayish-sericeous basal leaves, long racemose to paniculate stems and their long, thin branches (Phitos 1965; Fedorov \& Kovanda 1976).

Our results show that $C$. topaliana subsp. delphica has also a diploid $(2 n=2 \mathrm{x}=34)$, symmetrical karyotype comprised of mostly metacentric (m) and submetacentric (sm) chromosomes (Fig. 4c); one pair of submetacentric (sm) SAT-chromosomes is observed in most metaphase plates (Fig. 4d). The chromosome size varies between 0.83 and $1.17 \mu \mathrm{m}$ (Table 1). To our knowledge, these are the first chromosome data for the subspecies.

\section{Acknowledgements}

This research was supported by a grant to Eleni Liveri from the Greek General Secretariat for Research and Technology (GSRT) and the Hellenic Foundation for Research and Innovation (HFRI) (2017-2019). We would like to thank Mr. A. Karydas for the provided material of Campanula lavrensis and Mr. V. Ketsilis-Rinis for his assistance during field work. Finally, we are grateful to Prof. Emer. D. Phitos for his invaluable support.

\section{References}

Ade, A. \& Rechinger, K. H. 1938: Samothrake. - Repert. Spec. Nov. Regni Veg. Beih. 100: 106-146. Baliousis, E. 2016: New floristic records from the islands Psara and Antipsara (East Aegean, Greece). - Bot. Chron. (Patras) 21: 5-16.

Burton, R. M. 1991: A check-list and evaluation of the flora of Nisyros (Dodecanese, Greece). Willdenowia 20: 15-38.

Castroviejo, S., Aldasoro, J. J., Alarcón, M. \& Hand, R. 2010: Campanulaceae. Euro+Med Plantbase - the information resource for Euro-Mediterranean plant diversity. Published on the Internet http://ww2. bgbm. org/EuroPlusMed/ [Last accessed October 2020].

Cellinese, N., Smith, S. A., Edwards, E. J., Kim, S. T., Haberle, R. C., Avramakis, M. \& Donoghue, M. J. 2009: Historical biogeography of the endemic Campanulaceae of Crete. - J. Biogeogr. 36: 1253-1269. https://doi.org/10.1111/j.1365-2699.2008.02077.x

Chen, R. Y., Song, W. Q., Li, X. L., Li, M. X., Liang, G. L. \& Chen, C. B. 2003: Chromosome atlas of major economic plants genome in China, 3. - Beijing [in Chinese].

Contandriopoulos, J. 1964: Contribution à l'étude caryologique des Campanulacées de Grèce. Bull. Soc. Bot. France 111: 222-235. 
- 1970: Contribution à l'étude cytotaxinomique des Campanulacées du Proche Orient. - Bull. Soc.

Bot. France 117: 55-70. https://doi.org/10.1080/00378941.1964.10838197

Eddie, W. M. M. \& Ingrouille, W. J. 1999: Polymorphism in the Aegean "five-loculed" species of the genus Campanula, section Quinqueloculares (Campanulaceae). - Nordic J. Bot. 19: 153169. https://doi.org/10.1111/j.1756-1051.1999.tb00659.x

Fedorov, A. A. \& Kovanda, M. 1976: Campanula L. - Pp. 74-93 in: Tutin, T. G., Burges, N. A., Chater, A. O., Edmondson, J. R., Heywood, V. H., Moore, D. M., Valentine, D. H., Walters, S. M. \& Webb, D. A. (eds), Flora Europaea, 4. - Cambridge.

Fielding, J. \& Turland, N. 2005: Flowers of Crete. - Kew.

Gadella, T. W. J. 1964: Cytotaxonomic studies in the genus Campanula. - Wentia 11: 1-104.

Greuter, W. 1973: Additions to the flora of Crete, 1938-1972. - Ann. Mus. Goulandris 1: 15-83.

Higgins, M. D. 2009: Greek islands, Geology. Pp. 392-396 in: Gillespie, R. \& Clague, D. (eds), Encyclopedia of islands. Encyclopedias of the Natural World, 2. - Berkeley.

IUCN 1994: IUCN Red List Categories. - Gland: IUCN Species Survival Commission. https://portals.iucn.org/library/efiles/documents/1995-008.pdfIUCN

— 2003: Guidelines for Application of IUCN Red List Criteria at Regional Levels: version 3.0. IUCN, Gland \& Cambridge: IUCN Species Survival Commission.

Kougioumoutzis, K. \& Tiniakou, A. 2014: Network biogeographical analysis of the central Aegean archipelago. - J. Biogeogr. 41: 1848-1858. https://doi.org/10.1111/jbi.12342

_, - - Georgiadis, T. \& Georgiou, O. 2012a: Contribution to the flora of the South Aegean Volcanic Arc: the Methana Peninsula (Saronic Gulf, Greece). - Edin. J. Bot. 69(1): 53-81.

—, - - Georgiou, O. \& Georgiadis, T. 2012b: Contribution to the flora of the South Aegean Volcanic Arc: Anafi Island (Kiklades, Greece). - Willdenowia 42(1): 127-141. http://dx.doi.org/10.3372/wi42.42115

—, Simaiakis, S. M. \& Tiniakou, A. 2014: Network biogeographical analysis of the central Aegean archipelago. - J. Biogeogr. 41: 1848-1858. https://doi.org/10.1111/jbi.12342

Kyriakopoulos, Ch., Liveri, E. \& Phitos, D. 2017: Campanula kamariana (section Quinqueloculares), a new species from S Peloponnisos, Greece. - Fl. Medit. 27: 131-135. https://doi.org/10.7320/FlMedit27.131

Liveri, E., Crowl, A. A. \& Cellinese, N. 2019: Past, present, and future of Campanula (Campanulaceae) systematics - A review. - Bot. Chron. (Patras) 22: 209-222.

_, - Mavrodiev, E., Y1ldırım, H., Kamari, G. \& Cellinese, N. 2020: Another piece of the puzzle, another brick in the wall: The inevitable fate of Campanula section Quinqueloculares (Campanulaceae: Campanuloideae). - Taxon: 1-20. https://doi.org/10.1002/tax.12372

Marchal, E. 1920: Recherches sur les variations numériques des chromosomes dans la série végétale. - Mém. Acad. Belg. Cl. Sc. Ser. 2(4): 3-108.

Montmollin, B. de 1986: Étude cytotaxonomique de la flore de la Crète. III. Nombres chromosomiques. - Candollea 41: 431-439.

Papatsou, S. \& Phitos, D. 1975: Two new taxa from eastern Aegean. - Notes Roy. Bot. Gard. Edinburgh 34: 203-204.

Phitos, D. 1963a: Beiträge zur Kenntnis der Campanula rupestris-Gruppe. - Phyton (Horn) 10: 124-127.

— 1963b: Eine neue art der Gattung Campanula aus der Ägäis. - Mitt. Bot. Staatssamml. München 5: $121-124$. 
— 1964a: Trilokuläre Campanula-Arten der Ägäis. - Oesterr. Bot. Z. 111: 208-230.

— 1964b: Beiträge zur Kenntnis der südägäischen Campanula-Arten. - Ber. Deutsch. Bot. Ges. 77: 49-54.

- 1965: Die quinquelokulären Campanula-Arten. - Oesterr. Bot. Z. 112: 449-498.

- 1969: Cytotaxonomical study of the Campanula species (subsection Quinqueloculares) in Greece. - Post-doc dissertation, University of Patras, pp. 1-54 [in Greek with abstract in German].

— 1995a: Campanula laciniata L. - Pp. 124-125 in: Phitos, D., Strid, A., Snogerup, S. \& Greuter, W. (eds), The Red Data Book of Rare and Threatened Plants of Greece. - Athens.

— 1995b: Campanula merxmuelleri Phitos. Pp. 126-127 in: Phitos, D., Strid, A., Snogerup, S. \& Greuter, W. (eds), The Red Data Book of Rare and Threatened Plants of Greece. - Athens.

— 1995c: Campanula rupestris Sm. - Pp. 130-131 in: Phitos, D., Strid, A., Snogerup, S. \& Greuter, W. (eds), The Red Data Book of Rare and Threatened Plants of Greece. - Athens.

- 2016: The section Quinqueloculares of the genus Campanula (Campanulaceae) and its polymorphism: Taxonomic review of the last decades. - Bot. Chron. (Patras) 21: 91-102.

- \& Kamari, G. 1984: Cytotaxonomical contributions on the Flora of Crete. II. - Candollea 39: 447-451.

— \& - 1995: Campanula cymaea Phitos. - Pp. 116-117 in: Phitos, D., Strid, A., Snogerup, S. \& Greuter, W. (eds), The Red Data Book of Rare and Threatened Plants of Greece. - Athens.

— \& - 2009: Campanula merxmuelleri Phitos. - Pp. 185-186 in: Phitos, D., Constantinidis, T. \& Kamari, G. (eds), The Red Data Book of Rare and Threatened Plants of Greece, 1(A-D). Patras.

Runemark, H. \& Phitos, D. 1996: A contribution to the distribution of the genus Campanula section Quinqueloculares in Greece. - Bot. Chron. (Patras) 12: 5-8.

Sachpazi, M., Kontoes, C., Voulgaris, N., Laigle, M., Vougioukalakis, G., Sikioti, O., Stavrakakis, G., Baskoutas, J., Kalogeras, J. \& Lepine, J. C. 2002: Seismological and SAR signature of unrest at Nisyros caldera, Greece. - J. Volcanol. Geotherm. Res. 116: 29-33. https://doi.org/10.1016/S0377-0273(01)00334-1

Sibthorp, J. \& Smith, J. E. 1819: Flora Graeca, 3(1). - Londini.

Stojanov, N. \& Kitanov, B. 1944: Beitrag zur Kenntnis den Flora und der Vegetationsverhältnisse der Insel Samothrake. - God. Sofiisk. Univ. Fiz.-Mat. Fak., 3 (Estestv. Istorija) 40: 403-464 [In Bulgarian with German summary].

Strid, A. 2015: Reliquiae Runemarkianae: Chromosome numbers of angiosperms from the Aegean Islands. - Phytol. Balcan. 21(3): 245-293.

- 2016a: Atlas of the Aegean Flora, 1. Text \& Plates. - Englera 33(1): 1-700.

- 2016b: Atlas of the Aegean Flora, 2. Maps. - Englera 33(2): 1-878.

Sugiura, T. 1938: A list of chromosome numbers in angiospermous plants, V. - Proc. Imp. Acad. Tokyo 14(10): 391-392.

- 1942: Studies on the chromosome numbers in Campanulaceae. I. Campanuloideae Campanuleae. - Cytologia 12: 418-434. https://doi.org/10.1508/cytologia.12.418

Tibaldi, A., Pasquare, F. A., Papanikolaou, D. \& Nomikou, P. 2008: Tectonics of Nisyros Island, Greece, by field and offshore data, and analogue modelling. - J. Struct. Geol. 30: 1489-1506. https://doi.org/10.1016/j.jsg.2008.08.003

Tornadore, N., Popova, M. \& Garbari, F. 1974: Numeri cromosmici per la flora Italiana: 172-181. Inform. Bot. Ital. 6: 43-54. 
Zhukova, P. G. 1967: Karyology of some plants, cultivated in the Arctic-Alpine Botanical Garden. - Pp. 139-149 in: Avrorin, N. A. (ed.), Plantarum in Zonam Polarem Transportatio, 2. Leningrad [in Russian].

Addresses of the authors:

Eleni Liveri ${ }^{1}$, Pepy Bareka ${ }^{2} \&$ Kamari, Georgia ${ }^{1}$,

${ }^{1}$ Botanical Institute, Section of Plant Biology, Department of Biology, University of Patras, GR-26504 Patras, Greece. E-mails: eleniliveri@upatras.gr; kamari@upatras.gr

${ }^{2}$ Laboratory of Systematic Botany, Faculty of Crop Science, Agricultural University of Athens, Iera Odos 75, GR-11855 Athens, Greece. E-mail: bareka@aua.gr 